\title{
Context-specific indicators to guide the judgement of a going concern for a company in business rescue
}

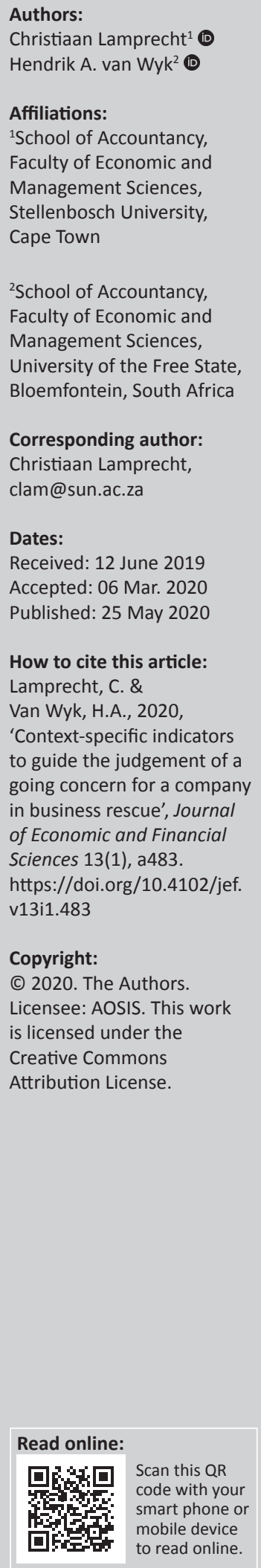

Orientation: Annual financial statements are normally prepared based on the going concern assumption that a company will continue to exist in the foreseeable future and that it has neither the intention nor the need to enter liquidation or to cease trading.

Research purpose: To establish indicators of a going concern in the context of a South African listed company under business rescue.

Motivation for the study: Current research is lacking in business rescue context-specific indicators of a going concern.

Research approach/design and method: A grounded theory method was followed by using a qualitative systematic interpretive literature review to identify possible indicators of a going concern in the context of a South African listed company under business rescue.

Main findings: In the context of a listed company under business rescue, financial distress, state of commercial and technical solvency and the foreseeable future are important indicators of its going concern status to be considered in combination with the particular business rescue aim pursued and stage of implementation of a business rescue plan.

Practical/managerial implications: The indicators would assist preparers and auditors of financial statements to assess appropriately the financial reporting assumption in a business rescue context.

Contribution/value-add: The findings provide guidance to preparers and users of financial statements and auditors by showing context-specific indicators of a going concern for use when preparing the financial statements of a South African listed company under business rescue.

Keywords: business rescue; financial reporting; going concern; IFRS, liquidation; underlying assumption.

\section{Introduction}

An entity shall prepare financial statements on a going concern basis unless management either intends to liquidate the entity or to cease trading, or has no realistic alternative but to do so.

(International Accounting Standards Board)

Annual financial statements of companies listed on the Johannesburg Stock Exchange (JSE) are normally prepared on the basis of the going concern assumption. The Conceptual Framework for Financial Reporting (CF) (International Accounting Standards Board [IASB] 2019a:A38) states that such an assumption implies that a company will continue to exist in the foreseeable future and that it has neither the intention nor the need to enter liquidation, or to cease trading. A management performs the going concern assessment at the time of preparing the financial statements and regards 'foreseeable future' as a period of at least 12 months from the end of the reporting period (IASB 2019b:A1101-A1102).

If a company has a history of profitable operations and ready access to financial resources, the management may conclude that the going concern assumption is appropriate without further detailed analysis. However, should that not be the case, the management may need to consider a wide range of factors before concluding that the going concern assumption is appropriate (IASB 2019b:A1102). A company that has filed for business rescue in terms of Chapter 6 of the South African Companies Act ('the Companies Act') is a case in point. A 'financially distressed' company that has a reasonable prospect of being rescued may apply for business rescue to reorganise its affairs to be able to continue to exist on a solvent basis, or if that is not possible, then to render a 
better return for creditors or shareholders than under immediate liquidation (Republic of South Africa [RSA] 2008:s 128(1)(b)(iii), 129(1)). 'Financial distress' is defined as the inability of the company to pay all of its debts as they become due and payable within the immediately ensuing 6 months or, alternatively, if it appears reasonably likely that the company will become insolvent within the immediately ensuing 6 months (RSA 2008:s 128(1)(f)). As a commencement requirement for entering business rescue operation, the financial distress test appears to be more stringent than the going concern assessment. If this is the case, any assessment of the going concern assumption when a company enters business rescue is problematic from the outset.

To complicate matters, most business rescue proceedings take, on average, 16 months to conclude (Klokow 2019). The average duration in excess of 12 months means that it is very likely that the company will have a financial year-end whilst under business rescue. In preparing the financial statements, the management has the difficult task of assessing whether the going concern assumption is appropriate. In this regard, International Financial Reporting Standards (IFRS) provide limited guidance to the preparer of financial statements of a company under business rescue. Moreover, the guidance is of a general nature and is understandably not specifically aimed at a South African listed company under business rescue.

This article addresses this gap. The purpose of the article was to establish possible context-specific indicators of a going concern for a South African listed company under business rescue through a qualitative interpretive systematic review of current context-specific literature regarding the going concern assessments. Considering the combined regulatory aspects of being listed, having applied for business rescue, the need to prepare financial statements and having these audited externally, a South African listed company under business rescue finds itself in a particular regulatory setting and was therefore chosen as the subject of investigation.

Assessing whether the going concern assumption is appropriate is important for various interested parties, other than the management. Users of financial statements require decision-useful information, and the appropriate assumption is an important consideration when assessing the financial wellness of the company from which they have borrowed funds, or in which they intend to invest or divest. Auditors, being the external adjudicators of financial statements, are tasked to judge the management's assessment regarding the applicability of the going concern assumption. Standard setters may be interested in the fact that, in some instances, a company is not necessarily a going concern and neither it is in liquidation (or liquidation is not intended). In fact, the IASB decided to discontinue a project on disclosure requirements when assessing a going concern but to discuss the issues as part of the disclosure initiative (Deloitte 2014). All the above-mentioned parties can benefit from contextspecific indicators of a going concern with respect to a South
African listed company under business rescue. However, although the article focusses on a listed company, the preparer and reviewer of financial statements for small and medium-size companies may equally benefit from the findings of this article.

\section{Research question}

To offer standard setters, preparers and users guidance when considering the appropriateness of the going concern assumption, this article explores the phenomena of a South African listed company under business rescue and the possible indicators of a going concern whilst under business rescue. The following research question steers the research in establishing business rescue context-specific indicators of a going concern: What are the possible context-specific indicators of a going concern for a listed company under business rescue?

The remainder of the article is structured as follows: The next section explains the research design and its constituent elements, followed by the research findings. A summary of key findings and limitations are then highlighted. The article concludes with some final thoughts on the indicators identified to assess the going concern status of a South African listed company under business rescue and identifies areas for further research.

\section{Research design}

Table 1 summarises the various components of the research design employed to address the research problem. A brief elaborative discussion follows Table 1.

\section{Research philosophy}

The research problem addressed in this article is of practical nature, namely to establish context-specific indicators on whether or not a listed company under business rescue could be considered a going concern. The problem is therefore addressed exploratively by using a pragmatism research philosophy. In pragmatism, the aims are to contribute to practical solutions that inform the future practice (Saunders, Lewis \& Thornhill 2016:143). Pragmatism also allows researchers to choose a philosophical position on a continuum between an interpretive and positivist ontology. Researcher values are important and drive the process of reflection (Saunders et al. 2016:143, 170). Epistemologically, knowledge is gained by seeking what will work to solve the problem, and the knowledge can consist of opinions and narratives as well as generalisable objective facts.

\section{Theoretical basis}

The CF states that the objective of general-purpose financial reporting is to 'provide financial information about the reporting entity that is useful to existing and potential investors, lenders and other creditors in making decisions about providing resources to the entity' (IASB 2019a:A22). The decision-usefulness of financial statements is paramount and provides the overarching theoretical basis for this article. 
TABLE 1: Research design components.

\begin{tabular}{|c|c|}
\hline Components & Description \\
\hline Purpose & Exploratory \\
\hline Conceptualisation and mode of reasoning & Theoretical and abductive \\
\hline Research paradigm & $\begin{array}{l}\text { Ontology: Pragmatism } \\
\text { Epistemology: Practicality - what works }\end{array}$ \\
\hline Research approach & Qualitative (application of grounded theory principles) \\
\hline Research question or problem & What are the possible indicators of a going concern for a company under business rescue? \\
\hline Context & A South African company under business rescue \\
\hline Propositions & $\begin{array}{l}\text { (1) The aspects influencing the going concern assessment in the context of a listed company under business rescue are clear. } \\
\text { (2) Possible business rescue context-specific indicators of a going concern can be established. }\end{array}$ \\
\hline Phenomena investigated & Going concern indicators for a listed company under business rescue \\
\hline Mode of observation & Systematic qualitative literature review \\
\hline Units of observation & $\begin{array}{l}\text { - Local literature addressing the context of a listed company under business rescue } \\
\text { - Local and international literature addressing the going concern financial reporting assumption }\end{array}$ \\
\hline Logic linking the data to the propositions & $\begin{array}{l}\text { Local literature that can explain the context of a listed company under business rescue is available. The possible indicators of a } \\
\text { going concern could be established from a systematic review of the relevant local and international literature. }\end{array}$ \\
\hline Criteria for interpreting the findings & $\begin{array}{l}\text { - The context of a listed company under business rescue can be established. } \\
\text { - Themes that arise from the systematic review of the relevant literature that will indicate the possible indicators of a going } \\
\text { concern for a South African listed company under business rescue. }\end{array}$ \\
\hline
\end{tabular}

Source: Adapted from Mouton, J., 2001, How to succeed in your master's and doctoral studies: A South African guide and resource book, pp. 152-153, Van Schaik Publishers, Pretoria; Olalere, T., 2011, Methodology in accounting research: A critique of taxonomy, p. 18, viewed 23 January 2018, from https://papers.ssrn.com/sol3/papers.cfm?abstract_id=1921192; Yin, R.K., 2018, Case study research and applications: Design and methods, p. 27, Sage, Los Angeles, CA.

The theory of decision-usefulness is concerned with the objectives of financial statements, who the users of the financial statements are, and to anticipate what their information needs are (Deegan 2014:12; Ryan, Scapens \& Theobald 2002:102). A theory that prescribes what should be carried out under particular circumstances, as opposed to describing what has been carried out or predicting what happens, is known as a normative theory of accounting (Deegan 2014:12). According to Deegan (2014:213), the CF of the IASB could be viewed as a normative theory of accounting.

The $\mathrm{CF}$, as a decision-useful prescriptive theory of accounting, prescribes the going concern financial reporting assumption, unless liquidation is intended or unavoidable (IASB 2019:A38). A listed company that has filed for business rescue finds itself in a unique and difficult position. Having filed for business rescue does not necessarily show an intent to liquidate or to cease trading, or that it may be the last resort. However, it seems that IFRS defaults to applying the going concern assumption in the absence of the above-mentioned intentions. This article aims to extend the existing theory on decision-usefulness, as evident in the $\mathrm{CF}$, by offering indicators to guide preparers and users when assessing or interpreting the appropriateness of the going concern financial reporting assumption.

Saunders et al. (2016:193) argue that the grounded theory can be used to explore a wide range of business and management activities, as much of business and management concerns people's behaviours. Grounded theorists may use the existing theory (in this case the decision-usefulness theory of accounting) before the research to inform the research in general terms but not to influence the data coding and analysis (Saunders et al. 2016:195). Data coding and analysis are executed by using the grounded theory as a method (Booth, Papaioannou \& Sutton 2012:150) to allow the concepts (in this case the possible indicators of a going concern) to emerge from the data. These concepts or themes are used to offer guiding recommendations with respect to the assessment of the appropriateness of the going concern assumption to extend the existing body of knowledge as it relates to the CF.

\section{Research methodology}

The article aims to add to the existing theory of decisionusefulness by prescribing useful indicators of a going concern in the context of a company under business rescue. This is carried out following an exploratory qualitative systematic review methodology (Moustaghfir 2008:11). The systematic literature review was approached by using the Search, AppraisaL, Synthesis and Analysis (SALSA) framework of Booth et al. (2012:25-30).

A purposive search strategy was employed across various electronic library databases and, where applicable, Internet sources. The search covered studies published since 2011 in English by using the keywords such as 'going concern', 'liquidation', 'business rescue', 'corporate renewal', 'financial reporting underlying assumption', 'decision usefulness', 'financial reporting' and 'basis of accounting'. The search strategy was complemented by checking of reference lists (Booth et al. 2012:84) of main sources retrieved.

The abstracts and other information were appraised critically for quality (i.e. validity, reliability and applicability with respect to the phenomenon and the research problem) and, once included, to categorise the information for further synthesis and analysis. The categorised literature was reviewed to identify those factors or indicators that are significant to understand the phenomena and to address the research problem before organising these factors into main themes (Booth et al. 2012:148).

The process concluded with an analysis of the literature to find indicators of a going concern in a business-rescue context. 
The researchers kept indicators at a high level, for example, 'State of commercial solvency' was used when several ratios could be used as individual indicators of liquidity. Theoretical saturation was reached when the identified indicators were considered sufficient to address adequately the research question.

The required ethical clearance was obtained from the researchers' institution. With respect to the trustworthiness and whether enough studies are consulted when using a purposive search strategy in a systematic qualitative literature review approach (Booth et al. 2012:179), we aimed for a manageable number of high-level indicators. The researchers explored the indicators that they thought might influence the going concern assumption assessment for a company under business rescue. The next section discusses the findings with respect to the two propositions investigated in this article.

\section{Ethical consideration}

Ethical approval was obtained from the Ethics Committee of the University of the Free State, Bloemfontein (Ethical Clearance Number: UFS-HSD2014/0302, 31 July 2014).

\section{Findings}

The article addressed two propositions, namely that the regulatory aspects influencing the going concern assessment in the context of a listed company under business rescue are clear, and that possible context-specific indicators of a going concern can be established. The findings linked to each of the propositions are discussed below.

\section{Findings linked to proposition 1: The regulatory aspects influencing a going concern assessment}

By using the SALSA review process, four regulatory aspects were identified that might influence the going concern assessment in the context of a listed company under business rescue. These aspects are shown in Figure 1.

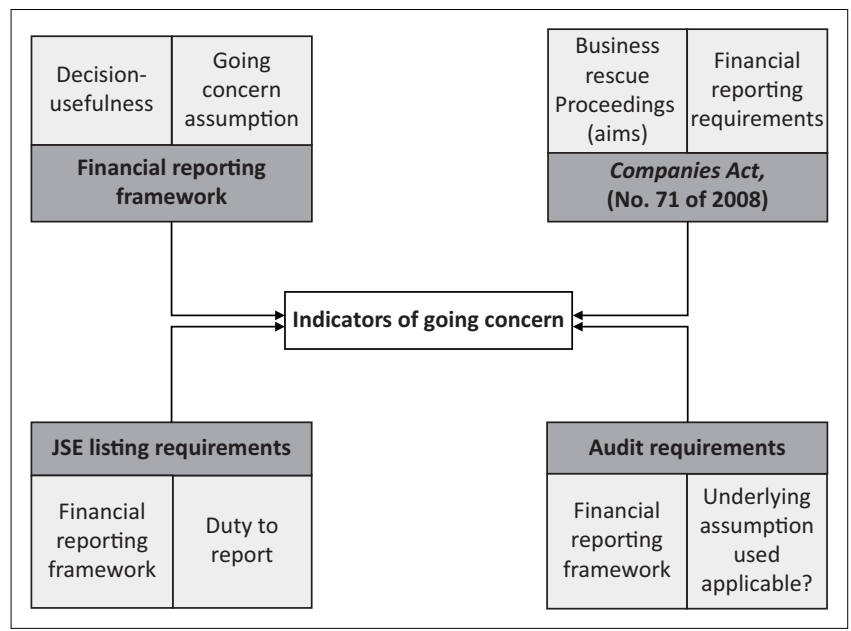

JSE, Johannesburg Stock Exchange.

FIGURE 1: Going concern assessment in the context of a listed company under business rescue.
The four regulatory aspects that may influence the going concern assessment are discussed below.

\section{Financial reporting framework}

The first regulatory aspect is the fact that the management should perform going concern assessment at the time of preparing financial statements in terms of the CF (IASB 2019b:A1101-A1102). This assessment is performed against the backdrop of an overarching objective of general purpose financial reporting, namely to 'provide financial information about the reporting entity that is useful to existing and potential investors, lenders and other creditors in making decisions about providing resources to the entity' (IASB 2019a:A22). Indicators of a going concern should therefore be used by management to fulfil their obligation to provide decision-useful financial statements.

\section{Companies Act (Act 71 of 2008)}

Companies in financial distress may file for business rescue protection in terms of the South African Companies Act, the second regulatory aspect, which may influence the assessment of whether or not a company is a going concern. By filing for business rescue protection, the management of the company is temporarily transferred to a business rescue practitioner (BRP) (RSA 2008:s 128(1)(b)(i)). The BRP is required to develop and implement a business rescue plan (RSA 2008:s 140(d)), pursuing effectively one of the two aims. The primary aim of the proceedings is to enable the company to continue in existence on a solvent basis (hereafter referred to as aim 1 - return to solvency [RTS]). However, if that is not possible, the secondary aim is to provide a better return for the company's creditors or shareholders than would result from the immediate liquidation of the company (hereafter referred to as aim 2 - better return than under liquidation [BRIL]) (RSA 2008:s 128(1)(b)(iii)).

Because most business rescue proceedings take, on average, 16 months to conclude (Klokow 2019), it is therefore likely that a financial year-end will occur whilst under business rescue. Johannesburg Stock Exchange-listed companies required to apply IFRS (RSA 2008:s 29(5)), and the BRP (now acting as management) must therefore consider the applicability of the going concern financial reporting assumption when the financial statements are prepared. Moreover, these financial statements must still be audited (RSA 2011:s 27(4)), and the auditor will consider the chosen financial reporting assumption against the particular financial reporting framework used (International Auditing and Assurance Standards Board [IAASB] 2018a:110, 2018b:583) as part of the audit process.

\section{Audit requirements}

The third regulatory aspect that has emerged involved the audit of the company. The 2008 Companies Act determines that the financial records of a listed company shall be audited (RSA 2008:s 30(2)(a)), and they shall be audited in terms of the Auditing Profession Act, 2005 (Act 26 of 2005) (RSA 2008:s 1('audit')). The Auditing Profession Act established the 
Independent Regulatory Board for Auditors (IRBA) as the regulatory body for registered auditors in South Africa (SA). In 2009, the IRBA adopted the IAASB's International Standards on Auditing and Quality Control (RSA 2009). All audits on listed companies are therefore carried out in terms of these auditing standards. The International Standards on Auditing (ISA) require that the auditor, amongst other things, determine whether the financial reporting framework applied in the preparation of financial statements is acceptable (IAASB 2018a:110) and whether the use of the going concern financial reporting assumption by management is appropriate for preparing financial statements (IAASB 2018b:583). The auditor's view is important as the auditing literature contains more guidance on the appropriateness of the going concern financial reporting assumption for preparing financial statements than that currently available under the IFRS.

\section{Johannesburg Stock Exchange listing requirements}

Companies listed in the JSE should comply with its listing requirements, and may also influence the assessment of whether or not the company is a going concern. The JSE listing requirements are therefore the fourth regulatory aspect that can indirectly influence the going concern assessment. The JSE requires all listed companies to implement the IFRS reporting framework (JSE 2019:par. 8.57(a, c) \& 8.62(b)). The JSE further requires that every issuer should distribute audited annual financial statements for relevant financial year to all holders of securities within 6 months after the end of the financial year (JSE 2019:par. 3.19). However, if the annual financial statements have not been distributed to all shareholders within 3 months of the issuer's financial year end, it must distribute and publish provisional annual financial statements ('provisional reports') within the 3 months following the end of the financial year (JSE 2019:par. 3.16(a), 3.20). The provisional reports may be unaudited but must still be prepared in accordance with the CF and the measurement and recognition requirements of IFRS (JSE 2019:par. 8.57 (b)). The management is therefore still required to assess the appropriateness of the going concern financial reporting assumption when preparing financial statements. Furthermore, this assessment has to be carried out within 4 months after the year end. It is likely that a listed company with a reporting date whilst under business rescue will still be under business rescue 4 months after the year end.

In summary, the findings revealed four important aspects or vantage points, which may influence directly or indirectly the assessment of whether a company is a going concern when it is under business rescue. These regulatory aspects were used as a starting point in reviewing relevant literature to identify and establish possible indicators of a going concern in a business rescue context.

\section{Findings linked to proposition 2: Possible business rescue contextualised indicators of a going concern}

The purpose of the article was to establish possible useful indicators of a going concern in the context of a listed company under business rescue. The four aspects that may influence the going concern assessment of a listed company under business rescue, namely the financial reporting framework, Companies Act, audit requirements and the JSE listing requirements, were used in the SALSA review as a guiding structure to identify and analyse relevant literature in the context of research problem. Table 2 lists the findings. The findings are presented with an indication of the perspective from which it originated, the final coding items after data saturation occurred as well as how these codes have been collapsed into themes that serve as high-level indicators in a going concern assessment for a listed company under business rescue.

Note 1: Code 2 (liquidation) and code 3 (cessation) are clear indicators of not being a going concern. However, the codes are disregarded from further analysis, as a company filing for business rescue had to prove a reasonable prospect of

TABLE 2: Possible indicators of a going concern.

\begin{tabular}{|c|c|c|c|}
\hline Perspective & Code No. & Code name & Themes \\
\hline FRF, AR & 1 & Foreseeable future & Foreseeable future \\
\hline FRF & 2 & Liquidation (Note 1) & $\mathrm{N} / \mathrm{A}$ \\
\hline FRF & 3 & Cessation of trading (Note 1 ) & N/A \\
\hline FRF & 4 & Deterioration in operating results & State of commercial solvency \\
\hline FRF & 5 & Deterioration in financial position & State of technical solvency \\
\hline FRF, AR & 6 & Assets and liabilities realised and settled in the normal course of business & Financial distress and realisation of assets and liabilities \\
\hline AR, JSE & 7 & Action 1: Substantial disposition of assets outside the ordinary course of business & Triggering event: Actions to rescue company \\
\hline AR & 8 & Action 2: Restructuring of debt & Triggering event: Actions to rescue company \\
\hline AR & 9 & Action 3: Externally forced revisions of its operations & Triggering event: Actions to rescue company \\
\hline CA, JSE & 10 & Duration of proceedings or point in time & Duration or period \\
\hline CA & 11 & Aims of the business rescue proceedings & Aims of business rescue \\
\hline CA & 12 & Action 4: Materially scaling down of operations & Triggering event: Actions to rescue company \\
\hline CA, JSE & 13 & Commercial insolvency & State of commercial solvency \\
\hline CA, JSE & 14 & Technical insolvency & State of technical solvency \\
\hline FRF, AR, CA & 16 & Triggering events & Triggering event: Actions to rescue company \\
\hline FRF, AR & 17 & Ratio analysis & State of technical solvency \\
\hline
\end{tabular}

FRF, financial reporting framework; AR, audit requirements; CA, Companies Act; JSE, Johannesburg Stock Exchange. 
being rescued. In other words, the company does not intend to enter liquidation or cease operations.

Codes given in Table 2 are discussed hereunder within the four regulatory aspects that can indirectly influence the going concern assessment.

\section{Financial reporting framework}

The CF, as well as the two reporting standards, specifically addresses the going concern financial reporting assumption. The CF states that an entity is a going concern when it is able to remain in existence for the foreseeable future (IASB 2019a:A38). The term 'foreseeable future' (code 1) is an important indicator, yet the CF does not define the construct. According to Hahn (2011:31), 'foreseeable future' generally refers to a period of at least, but not limited to, 12 months after the end of the reporting period. The CF further defines what is not considered a going concern, that is, the entity has neither the intention nor the need to enter liquidation (code 2) or cease trading (code 3).

International Accounting Standard (IAS) 1 deals with the presentation of financial statements and echoes the CF in its requirement that an entity should prepare financial statements on a going concern basis unless the management intends either to liquidate (code 2 ) the entity or cease trading (code 3), or has no realistic alternative but to liquidate (IASB 2019b:A1101). International Accounting Standard 10 (IASB 2019c), dealing with events after the reporting period, uses the same wording elsewhere in the standard where it states the following:

$[A] n$ entity shall not prepare its financial statements on a going concern basis if management determines after the reporting period either that it intends to liquidate the entity or to cease trading, or that it has no realistic alternative but to do so (codes 2 and 3). (p. A1212)

Furthermore, IAS 10 notes that a deterioration in operating results (code 4) and financial position (code 5) after the reporting period may indicate a need to consider whether the going concern assumption is applicable or not (IASB 2019c:A1212).

In an important enquiry commissioned by the UK Financial Reporting Council (FRC) into a going concern and liquidity risks, the panel found that to depart from the going concern basis of accounting, the threshold of distress required by the Generally Accepted Accounting Practice in the UK (UK GAAP) and IFRS framework would be at a very high and imminent level (Financial Reporting Council [FRC] 2012:2, 25). The report therefore reaffirms that the underlying financial reporting assumption of a going concern would be used unless the company has no realistic alternative to cease trading (code 3 ) or go into liquidation (code 2) or the directors intend to do so. Moreover, the report warns that providing additional disclosures regarding material uncertainties when the going concern reporting assumption has been adopted still means that there is a very high level of risk that the company may not be able to remain a going concern for the foreseeable future (code 1) (FRC 2012:2). Referring to solvency risk, the report also identified risks to the entity's business model (code 15) (such as the inability to make new investments essential to sustain the business) and triggering events (such as an emergency rights issue) (code 16) outside the ordinary course of business plans as important indicators that the company is not a going concern (FRC 2012:10). Aras and Crowther (2012:22) also argue for a consideration of the principles of sustainability of the company (code 15) when assessing the company as a going concern. The Turnaround Management Association (TMA) states that the cash flow contributions of different business units and their overall strategies and risks (code 15) should be understood when preparing a cash flow forecast for a turnaround (Turnaround Management Association [TMA] 2011:2-1). Regarding strategy, Harvey (2011:19, 22 \& 89) argues that the competitiveness of the product or service will be one of the most important elements in the turnaround strategy.

Several studies referred to the use of ratio analysis (code 17) in various forms to assess a going concern, for example, Koh and Low (2004) used financial ratios and data mining techniques to predict a going concern, Holzmann (2010:80) referred to adverse key ratios and Bhimani, Gulamhussen and Lopes (2009) used various cash-flow-related variables, amongst others, in an empirical logit model. In the context of this article, ratio analysis (code 17) points to the state of solvency, and an in-depth study of the various ratios used falls outside the ambit of this article.

\section{Companies Act, Act $\mathbf{7 1}$ of $\mathbf{2 0 0 8}$}

The Companies Act has an influence on the financial reporting of a South African listed company under business rescue through its requirement to comply with IFRS in preparing their financial statements (RSA 2008:s 29(5), 2011:s 27(4)). It was earlier pointed out that it currently takes nearly 16 months, on average, to conclude business rescue proceedings (Klokow 2019). Because a reporting date may occur at any stage during the business rescue proceedings, it is necessary to consider the point in time during the proceedings when the foreseeable future consideration could be made. This is important because the stage of implementation of the business rescue plan may have an effect on the consideration of the foreseeable future at a point in time during the implementation of the plan, further impacting the going concern assessment. For purposes of this article, the proceedings are divided into two stages, which can be further divided into four periods. The first stage, also period 1, encompasses the time from filing for business rescue up to the time the business rescue plan is adopted by the affected parties. Because the company has just filed for business rescue based on the financial distress as defined, the foreseeable future may be severely limited during this period because of significant uncertainties. The second stage stretches from the adoption of the business rescue plan up to the substantial implementation of the plan and can be divided into three further periods. Figure 2 illustrates these stages and the periods within those stages. 


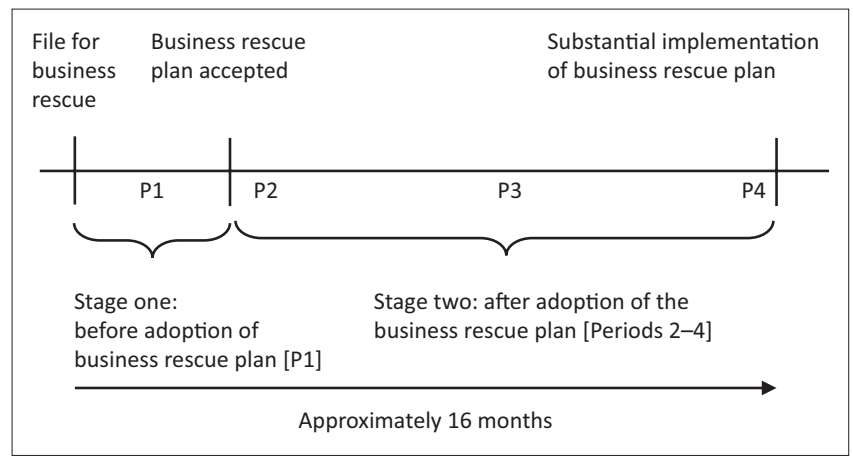

P1: Period from filing for business rescue up to adoption of the business rescue plan.

$\mathrm{P} 2$ : Just after the adoption of the business rescue plan.

P3: Halfway through the implementation of the plan.

P4: Just before substantial implementation of the plan.

FIGURE 2: Business rescue duration and stages of implementation.

Another important consideration is the aims of the business rescue (code 11) proceedings. It was earlier indicated that there are two aims of business rescue, namely either to continue in existence on a solvent basis (aim 1 - RTS) or to realise a better return for creditors and shareholders than under immediate liquidation (aim 2 - BRIL) (RSA 2008:s 128(1) (b)(iii)). The mutual exclusivity of the two objectives is also implied by several commentators. Loubser (2013:13) noted that the 'better return to creditors' principle, a second acceptable objective of company administrations in England, was copied by the legislature. Pretorius $(2015: 21,40)$ refers to aim 2 - BRIL as an alternative goal and indicates that many BRPs consider this option valuable and would pursue it immediately. Levenstein (2015) noted the following two plans:

If a plan cannot be devised to rescue the company under the provisions of Chapter 6 , then a plan that would achieve a better return for a company's creditors than that which would ensue pursuant to its winding-up is the next alternative objective. (p. 276)

Interestingly, Bradstreet (2014) considers aim 2 - BRIL as an 'orderly liquidation', and Loubser (A. Loubser stated through verbal communication with C.L., 05 March, 2015, Johannesburg) argues that BRIL should lead to the dissolving of the company once business rescue proceedings have been concluded. It follows then that a material scaling down of operations would be the part of business rescue plan to render a better return for creditors. Anecdotal evidence in the form of personal communication with senior BRPs confirmed a mutually exclusive view of business rescue aims. These BRPs indicated that they would choose either aim 1 - RTS or aim 2 - BRIL as their strategy from the outset (T. Flynn stated in a verbal communication with C.L. on 14 August 2014 at Cape Town; and L. Matuson also stated through verbal communication with C.L. on 04 March 2015 at Johannesburg).

Considering the apparent stringent definition of financial distress as discussed earlier, two factors need to be considered. Firstly, the inability of the company to pay all of its debts as they become due and payable within the immediately ensuing 6 months (commercial insolvency - code 13) and secondly, how likely it is that the company will become insolvent within the immediately ensuing 6 months (technical insolvency - code 14) (RSA 2008:s 128(1)(f)). Braadveldt (2018) notes that the concept of financial distress is built on the principles of liquidity (code 13) and solvency (code 14). Rushworth (2010:377) referred to a cash-flow (code 13) insolvency and balance sheet (code 14) tests. The South African Institute of Chartered Accountants (SAICA) issued guidance with respect to the solvency and liquidity test (codes 13 and 14) in the Companies Act. Although SAICA recommends a detailed cash flow analysis for at least 12 months (code 1) when performing a liquidity test (South African Institute of Chartered Accountants [SAICA] 2012:23), they also argue that commercial insolvency (code 13) is likely to indicate that a going concern problem exists (SAICA 2007:1). Considering that the going concern assessment is performed for the ensuing 12 months (from the reporting date), as opposed to a financial distress test covering the ensuing 6 months (from the date the test is performed), it follows that the financial distress test appears to be more stringent. This may be more evident when the reporting date and the date of entering business rescue is close to each other, as a business rescue plan to rescue the company and to change its fortunes may not have been adopted.

Section 142 of the Companies Act sets out a list of matters that should be included in a statement of affairs that should be provided to the BRP. On the supposition that this information should assist the BRP in deciding whether the company can be rescued, the details of what the legislature had in mind are of importance. The Companies Act requires particulars of material transactions involving the company or its assets that occurred within 12 months before the rescue proceedings commenced (code 16, that may also include codes 7-9 and 12), the assets and liabilities of the company (code 14), income and disbursements within the previous 12 months (code 4) (RSA 2008:s 142(3)).

Since the introduction of the Companies Act, Act 71 of 2008 in 2011, a growing body of research literature addresses business rescue from a legislative point of view. For example, with respect to liquidation, Loubser (2013:1) argues whether the South African business rescue regime will remain unsuccessful, because it serves as a vehicle to fight company liquidations, and Sher (2014:iii) investigates the appropriateness of business rescue as opposed to liquidation from the viewpoint of the courts. On the topic of the foreseeable future, Joubert (2013:550) examines the way in which the judiciary dealt with the reasonable prospect requirement. Pretorius (2013:1, 8) researched legislated activities of the BRP through the lens of business strategy and performance (business model or sustainability), and the topic of post-commencement finance provisions (restructured debt) is investigated by Stoop and Hutchison (2017:1). In the context of this article, the corpus of legislative literature mainly addresses elements (codes) that have been already identified through the Companies Act, resulting in no new codes emerging from the systematic review. 


\section{Audit requirements}

According to Chen and Church (1996:117), users of financial statements are particularly interested in the auditor's assessment of the appropriateness of the going concern financial reporting assumption. International Standards on Auditing No. 570 deals with the auditor's responsibility in the audit of financial statements when the management prepares the financial statements on the going concern assumption (IAASB 2018b:583). Once again, ISA No. 570 (IAASB 2018b:583) states that financial statements prepared under the going concern assumption that the entity will continue its operations in the foreseeable future (code 1). However, it adds that when the going concern basis is appropriate, its assets and liabilities will reflect the fact that these will be realised and settled in the normal course of business (code 6). The latter is echoed by FRC (2012:23) and Venuti (2004:42) and is important for this article, as a listed company that enters business rescue may not necessarily realise its assets and settle its liabilities in the normal course of business. International Standards on Auditing 570 (IAASB 2018b:585) cautions the auditor to remain alert throughout the audit for evidence of events or conditions (code 16) that may cast significant doubt on the entity's ability to continue as a going concern.

With respect to the auditing standards earlier applied in the USA, Pounder (2012:21) points out that the Statement of Auditing Standards (SAS) 126 on the auditor's consideration of an entity's ability to continue as a going concern does not define what a going concern is, but rather what a going concern is not. The SAS 126 states that if the auditor has:

[S]ubstantial doubt about the entity's ability ... to continue to meet its obligations as they become due without substantial disposition of assets outside the ordinary course of business (code 7), restructuring of debt (code 8), externally forced revisions of its operations (code 9) or similar actions.

Then the entity ordinarily would not be considered able 'to continue as a going concern'. The SAS 126 was subsequently harmonised with ISA 570 as AU-C Section 570 - The Auditor's Consideration of an Entity's Ability to Continue as a Going Concern (ASB 2015). AU-C 570 retained the paragraph that Pounder (2012) has referred to above in its scoping section (\$570.02). Interestingly, a subsequent revision of AU-C 570 removed these actions describing what is not a going concern from the scope of the standard (ASB 2018). Nevertheless, these actions or triggering events are, in fact, some of the actions that a South African listed company under business rescue may just need to implement during the business rescue proceedings, and were retained for further thematic analysis.

\section{Johannesburg Stock Exchange listing requirements}

In line with the 2008 Companies Act, the JSE listing requirements also require IFRS to be applied to the financial statements of listed companies (JSE 2019:par. 8.57[(a), (c) \& 8.62(b)). Therefore, in preparing its financial reports, such as its annual financial statements, the management would have to consider the going concern assumption in terms of IFRS. The earlier indicated possible indicators of a going concern are therefore indirectly supported via the JSE listing requirements.

The JSE may suspend listing of securities where an issuer is placed under business rescue proceedings in terms of Chapter 6 of the Companies Act (JSE 2019:par. 1.10(a)(iii)). However, during a suspension, the company must, unless the JSE decides otherwise, continue to comply with all the listing requirements applicable to it (JSE 2019:par. 1.11(a)(iii)). One area needs to be highlighted: Schedule 11 of the JSE listing requirements allows a company in severe financial difficulty to dispose of a substantial part of its business (code 7) or issue shares for cash within a short time frame to meet its ongoing working capital requirements (liquidity - code 12) or to reduce its liabilities (solvency - code 13) when time constraints would not allow convening a shareholders meeting to obtain the required approval (JSE 2019:s. 11). Apart from the expedited procedures regarding shareholders' approval as stated above, this article assumes that the JSE will not normally waive compliance with its listing requirements and that a listed company under business rescue will still be required to comply with the listing requirements.

\section{Summary of key findings: Themes emerging from the systematic review}

Users seek useful information from financial statements to aid with their economic decisions, that is, whether to lend to, invest in or divest from a company. Assessing whether a company is a going concern, even more so when the company is under business rescue, is an important step in the process of providing decision-useful financial information. The current assumption of a going concern, unless a company is in liquidation or has no realistic alternative but to do so, creates a problem for a company under business rescue. The findings presented in this article addressed this problem and have important implications for the going concern assessment when considered in the context of a South African listed company under business rescue. The key findings that emerged from the systematic analysis and its implications are summarised below.

Firstly, if a South African listed company enters business rescue, the financial distress in itself, as evident from the stringent financial distress test, is an indicator that it may not be a going concern, as it may not be any longer able to realise its assets and settle its liabilities in the normal course of business.

Secondly, the state of solvency (both commercial and technical), as an important indicator of financial distress should be considered together with the stage or period during the business rescue proceedings and for which of the aim the assessment is made. This distinction between the 
business rescue aims when considering the state of solvency is a major finding.

Thirdly, when a company is unable to meet its obligations as they become due and payable, certain actions should be taken to meet these obligations. The article reveals that should these actions or triggering events occur in a company under business rescue, it may significantly contradict the going concern assessment in the context of a South African listed company under business rescue. A few indicators appear to be more indicative in a business rescue context, namely a substantial disposition of assets outside the ordinary course of business, restructuring of debt, externally forced revisions of its operations, a material scaling down of operations and a change in the business model.

Fourthly, the foreseeable future assessment remains an important going concern indicator, but it should also be considered in terms of the stage or period of the proceedings as well as for which one of the pursued business rescue aims.

Conceptually, the article extends the theory of decisionusefulness when assessing whether a listed company under business rescue should be considered a going concern or not by emphasising certain business rescue contextualised indicators of a going concern. The indicators discussed above should be considered in combination and can be conceptually illustrated, as shown in Figure 3.

The conceptual model illustrates how the key findings intersect and can be used by the preparer of financial statements or the auditor in assessing whether a company is a going concern. The recent filing of the JSE-listed Group Five Limited (GRF) is a case in point. The company filed for

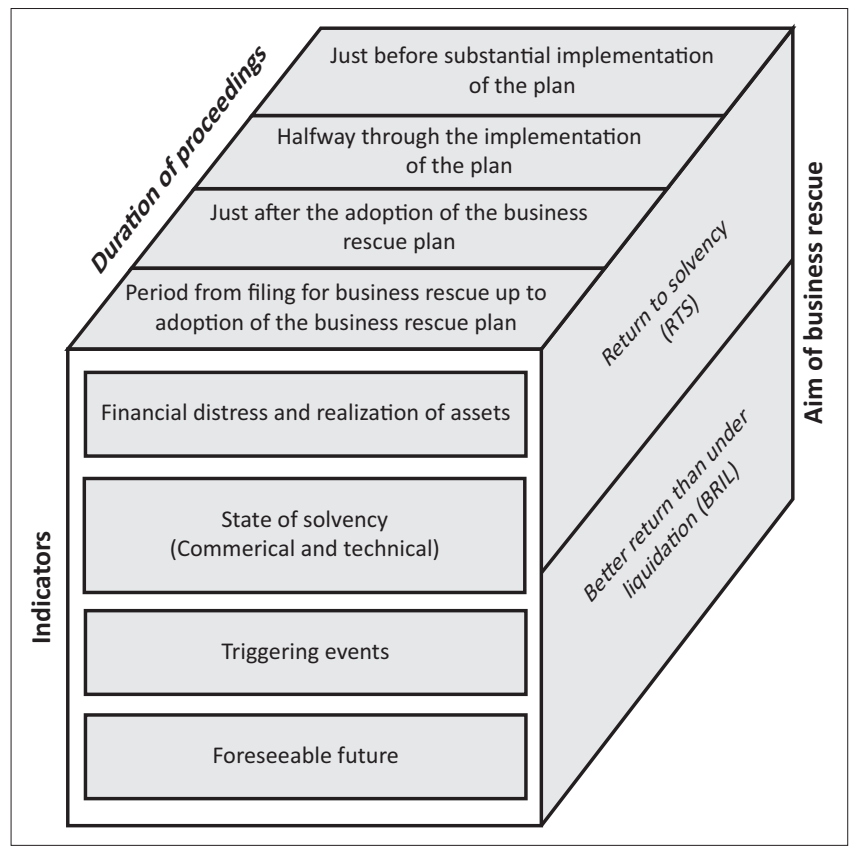

RTS, return to solvency; BRIL, better return than under liquidation.

FIGURE 3: Conceptual model of business rescue contextualised indicators of going concern. business rescue on 11 March 2019, a few months before its next reporting period ended on 30 June 2019. The business rescue plan was adopted on 11 September 2019, indicating a BRIL approach (Van der Steen \& Lake 2019:6, 13). ${ }^{1}$ Therefore, the preparer and the auditor need to consider the following in assessing the going concern status for purposes of financial statements: (1) The aim of business rescue proceedings was unknown at the reporting date, and subsequently indicated as BRIL. What are the possible consequences of that outcome? (2) The reporting date falls in the period from filing for business rescue but before adoption of a business rescue plan, inherently very uncertain and difficult period to assess the going concern status. In the case of GRF, it took more than 2 months after the reporting date for a plan to be adopted. (3) In assessing the foreseeable future, namely 12 months from the reporting date, what are the business rescue contextualised indicators telling us about the going concern status of the company? On the reporting date, one should consider the fact that GRF is already in financial distress, and possibly commercially insolvent. Are they also technically insolvent? Furthermore, the pressures of distress may likely trigger a substantial disposition of assets outside the ordinary course of business to raise much-needed working capital and/or a material scaling down of operations even before a rescue plan is published and adopted. Furthermore, news of the distress may lead to calling up of warranties and a need for extensive debt restructuring. One can therefore see that the going concern assessment is a dynamic assessment, of which the outcome is determined by the particular aim of business rescue pursued, the stage of proceedings and various indicators of a going concern to be considered.

Considering the findings discussed above, the resulting conceptual model and explanatory example of it, it is clear that the preparer or the auditor of financial statements and the BRP can benefit from the information that the others possess. Business rescue attempts suffer from an asymmetry of information (Pretorius 2016:483), and for that reason we recommend that the preparer or the auditor considers the following indicators when assessing the going concern assumption. Likewise, we recommend certain information to be made available in die business rescue plan to aid the preparer or the auditor. If implemented, these recommendations would reduce information asymmetry and enhance the decision usefulness of financial statements. Table 3 lists the going concern indicators for consideration by the preparer or the auditor and required information to be included in the business rescue plan.

\section{Limitations and the future research}

The study has several limitations, most notably researcher bias. The researchers attempted to limit the effect of researcher bias by following a rigorous qualitative systematic review process, such as the SALSA process. Another limitation is whether an adequate number of studies have 1.Authors' note: At the time of writing the article, the business rescue plan was still
being implemented, and the annual financial statements for the year ended 30 June 2019 have not been published. 
TABLE 3: Recommended going concern indicators for consideration by the preparer or the auditor and information to be included in the business rescue plan.

\begin{tabular}{lll}
\hline No. & Indicator & Preparer or auditor \\
\hline 1. & Business rescue aim & $\begin{array}{l}\text { Note the particular business rescue aim pursued (or engaged with BRP } \\
\text { pre-publication of the plan). }\end{array}$ \\
2. & Duration of proceedings & $\begin{array}{l}\text { Note during which stage of business rescue proceedings the reporting } \\
\text { period falls and consider the other indicators of a going concern taking } \\
\text { the stage of proceedings into account. Review any correspondence } \\
\text { between the BRP and the JSE for impact on the reporting obligations. }\end{array}$ \\
3. & Financial distress & $\begin{array}{l}\text { Consider whether the company can realise its assets and settle its } \\
\text { liabilities in the normal course of business, in combination with } \\
\text { indicators } 1 \text { and } 2 \text { above. }\end{array}$ \\
4. State of solvency & $\begin{array}{l}\text { Consider the state of solvency (both commercial and technical), by using } \\
\text { appropriate financial and non-financial measures, in combination with } \\
\text { indicators } 1 \text { and } 2 \text { above. }\end{array}$ \\
5. & Triggering events & $\begin{array}{l}\text { Consider actions or triggering events that may significantly contradict } \\
\text { the going concern assessment. Consider these events in combination } \\
\text { with indicators 1-4 above. }\end{array}$
\end{tabular}
Business rescue plan

Specifically note, in terms of the Companies Act legislation, which business rescue aim is pursued (RTS or BRIL).

The plan should note the financial reporting period as well as any reporting timelines and due dates. Specifically, note any JSE requirements on or waiving of reporting obligations.

Include a statement on whether the company can realise its assets and settle its liabilities in the normal course of business, and if not possible on entering business rescue, when it is anticipated that this may be the case.

Include a statement on the state of solvency (both commercial and technical) supported by appropriate key financial and non-financial measures.

Specifically note whether the following actions are anticipated during rescue proceedings, and if so, when:

- A substantial disposition of assets outside the ordinary course of business.

- Restructuring of debt.

- Externally forced revisions of its operations.

- A material scaling down of operations.

- A change in the business model.

6. Foreseeable future Consider the foreseeable future ( 12 months) from the reporting date, in Not applicable for purposes of the business rescue plan combination with indicators $1-5$ above.

RTS, return to solvency; BRIL, better return than under liquidation; JSE, Johannesburg Stock Exchange; BRP, business rescue practitioner.

been considered when using purposive sampling (Booth et al. 2012:179). The limitation was addressed by aiming for high-level indicators (i.e. the themes that emerged as discussed earlier) after theoretical saturation was reached. However, there are other indicators based on ratios, such as Altman's Z-score, that can also be used under certain conditions. The future research can test these indicators, initially developed using a different financial reporting framework for its applicability in a South African environment. We also submit that there may be several other non-financial indicators of a going concern risk. We suggest a future complementary research in this area in a South African context as well. Moreover, future research may also quantitatively explore the relationships between the different indicators of a going concern in the context of a listed company under business rescue.

\section{Conclusion}

The purpose of the article was to identify indicators of a going concern in the context of a South African listed company under business rescue. Current research does not address context-specific indicators of a going concern. The current accounting guidance sets a high bar for using any other assumption than the going concern assumption. The findings discussed in this article have important implications for preparers and users of financial statements. To this extent, the article reveals that in the context of a listed company under business rescue, financial distress and its impact on the realisation of assets and liabilities in the normal course of business are an important indicator that the company may not be a going concern. Moreover, as indicators of a going concern, the state of commercial and technical solvency, the foreseeable future and certain actions taken during the proceedings may be more indicative when considered in combination with the particular business rescue aim pursued and the stage of implementation of a business rescue plan.
We urge standard setters to consider developing more guidance regarding the assessment of going concern in the context of business rescue. We hope that the findings presented in this article will highlight the importance of such guidance and that this paper may also serve as a roadmap in developing appropriate guidance.

\section{Acknowledgements Competing interests}

The authors have declared that no competing interests exist.

\section{Authors' contributions}

C.L. authored the manuscript. H.A.V.W. provided strategic input and edited the manuscript.

\section{Funding information}

The research received no specific grant from any funding agency in the public, commercial or not-for-profit sectors.

\section{Data availability statement}

A summary of the coded data is available from the corresponding author upon request.

\section{Disclaimer}

The views and opinions expressed in this article are those of the authors and do not necessarily reflect the official position of any affiliated agency of the authors.

\section{References}

Aras, G. \& Crowther, D., 2012, 'Evaluating sustainability: A need for standards', Issues in Social and Environmental Accounting 2(1), 19-35. https://doi.org/10.22164/ isea.v2i1.23

Auditing Standards Board (ASB), 2015, 'AU-C section 570 the auditor's consideration of an entity's ability to continue as a going concern', in Statements on auditing standards, American Institute of Certified Public Accountants, pp. 573-581, Durham, CA. 
Auditing Standards Board (ASB), 2018, 'AU-C section 570 the auditor's consideration of an entity's ability to continue as a going concern', in Statements on auditing of an entity's ability to continue as a going concern', in Statements on auditing
standards, American Institute of Certified Public Accountants, pp. 581-605, standards, Ame

Bhimani, A., Gulamhussen, M.A. \& Lopes, S., 2009, 'The effectiveness of the auditor's going-concern evaluation as an external governance mechanism: Evidence from loan defaults', International Journal of Accounting 44(3), 239-255. https://doi. org/10.1016/j.intacc.2009.06.002

Booth, A., Papaioannou, D. \& Sutton, A., 2012, Systematic approaches to a successful literature review, Sage, London.

Braadveldt, K., 2018, The solvency and liquidity test in business rescue, viewed 22 March 2019, from https://www.tma-sa.com/info-centre/item/225-the-solvencyand-liquidity-test-in-business-rescue.html.

Bradstreet, R.S., 2014, Electronic communication with C. Lamprecht, 02 September 2014, Stellenbosch, Richard.Bradstreet@uct.ac.za.

Chen, K.C.W. \& Church, B.K., 1996, 'Going concern opinions and the market's reaction to bankruptcy filings', Accounting Review 71(1), 117-128.

Deegan, C.M., 2014, Financial accounting theory, 4th edn., McGraw Hill, Sydney, NSW.

Deloitte, 2014, FASB issues guidance on going concern, viewed 03 April 2019, from https://www.iasplus.com/en/news/2014/08/asu-2014-15.

Financial Reporting Council (FRC), 2012, The Sharman Inquiry - Going concern and liquidity risks: Lessons for companies and auditors. Final report and recommendation of the panel of inquiry, viewed 15 May 2019, from https://www.frc.org.uk/ getattachment/4a7f9880-0158-4cf0-b41e-b9e1bf006bd7/Sharman-Inquiry-finalreport-FINAL.pdf.

Hahn, W., 2011, 'The going-concern assumption: Its journey into GAAP', CPA Journal 81(2), 26-31, viewed 13 May 2019, from https://search.ebscohost.com/login.asp $x$ ?direct=true\&db=buh\&AN=59756814\&site=ehost-live.

Harvey, N., 2011, Turnaround management and corporate renewal: A South African perspective, Wits University Press, Johannesburg.

Holzmann, O.J., 2010, 'The going-concern assumption', Journal of Corporate Accounting \& Finance 21(6), 79-84. https://doi.org/10.1002/jcaf.20631

International Accounting Standards Board (IASB), 2019a, Conceptual framework for financial reporting. The annotated IFRS ${ }^{\circledR}$ standards Part A, IFRS Foundation, London

International Accounting Standards Board (IASB), 2019b, IAS 1 - Presentation of financial Statements. The annotated IFRS ${ }^{\circledR}$ standards Part A, IFRS Foundation, London.

International Accounting Standards Board (IASB), 2019c, IAS 10 - Events after the reporting period. The annotated IFRS ${ }^{\circledast}$ standards part A, IFRS Foundation, London.

International Auditing and Assurance Standards Board (IAASB), 2018a, 'ISA 210: Agreeing the terms of audit engagements', in Handbook of international quality control, auditing, review, other assurance, and related services pronouncements, International Federation of Accountants, pp. 107-131, New York, NY.

International Auditing and Assurance Standards Board (IAASB), 2018b, 'ISA 570: Going concern', in Handbook of international quality control, auditing, review, other assurance, and related services pronouncements, International Federation of Accountants, pp. 581-610, New York, NY

Johannesburg Stock Exchange (JSE), 2019, JSE listing requirements, viewed 16 May 2019, from https://www.jse.co.za/content/JSERulesPoliciesandRegulationltems/ JSE\%20Listings\%20Requirements.pdf.

Joubert, T., 2013, "Reasonable possibility" versus "reasonable prospect": Did business rescue succeed in creating a better test than judicial management?', Journal of Contemporary Roman-Dutch Law 76, 550-563.

Klokow, C., 2019, Business rescue proceedings status - December 2018, Companies and Intellectual Property Commission, Pretoria.

Koh, H.C. \& Low, C.K., 2004, 'Going concern prediction using data mining techniques', Managerial Auditing Journal 19(3), 462-476. https://doi.org/10.1108/02686900 410524436

Levenstein, E., 2015, 'An appraisal of the new South African business rescue procedure', Unpublished LLD thesis, University of Pretoria, Pretoria, viewed 14 May 2019, from https://hdl.handle.net/2263/56618.
Loubser, A., 2013, 'Tilting at windmills? The quest for an effective corporate rescue procedure in South African law', SA Mercantile Law Journal (SA Tydskrif Vir Handelsreg) 25(4), 437-457.

Moustaghfir, K., 2008, 'The dynamics of knowledge assets and their link with firm performance', Measuring Business Excellence 12(2), 10-24. https://doi.org/10.1108/ 13683040810881162

Mouton, J., 2001, How to succeed in your master's and doctoral studies: A South African guide and resource book, Van Schaik Publishers, Pretoria.

Olalere, T., 2011, Methodology in accounting research: A critique of taxonomy, viewed 23 January 2018, from https://papers.ssrn.com/sol3/papers.cfm?abstract $i d=1921192$

Pounder, B., 2012, 'Going concern gone', Strategic Finance 93(10), 21-22, 24, viewed 13 May 2019, from https://sunsfx.hosted.exlibrisgroup.com/sun?url_ver=Z39.88 2004\&rft_val_fmt=info:ofi/fmt:kev:mtx:journal\&genre=article\&sid=ProQ:ProQ\% 253 Aabiglobal $\&$ atitle $=\% 2522$ Going + Concern $\% 2522+$ Gone $\&$ title $=$ Strategic + Finan ce\&issn=1524833X\&date $=2012-04-01 \&$ volume $=93 \&$ issue $=10 \&$.

Pretorius, M., 2013, 'Tasks and activities of the business rescue practitioner: A strategy as practice approach', Southern African Business Review 17(3), 1-26.

Pretorius, M., 2015, Business rescue - Status quo report, Business Enterprises at the University of Pretoria, Pretoria.

Pretorius, M., 2016, 'The debtor-friendly fallacy in business rescue: Agency theory moderation and quasi relationships', South African Journal of Economic and Management Sciences 19(4), 479-496. https://doi.org/10.17159/2222-3436/2016/ v19n4a2

Republic of South Africa (RSA), 2008, Companies Act, No. 71 of 2008, Government Printer, Pretoria.

Republic of South Africa (RSA), 2009, Board notice 128 of 2009, Government gazette No. 32615 of 9 October 2009, viewed 07 May 2019, from https://opengazettes. org.za/gazettes/ZA/2009.html.

Republic of South Africa (RSA), 2011, Companies regulations, 2011, Government Printer, Pretoria.

Rushworth, J, 2010, 'A critical analysis of the business rescue regime in the Companies Act 71 of 2008: Business rescue: Part III', Acta Juridica 2010(1), 375-408.

Ryan, B., Scapens, R.W. \& Theobald, M., 2002, Research method and methodology in finance and accounting, 2nd edn., Thomson, London.

Saunders, M., Lewis, P. \& Thornhill, A., 2016, Research methods for business students, 7 th edn., Pearson Education, Harlow.

Sher, L.J., 2014, The appropriateness of business rescue as opposed to liquidation: $A$ critical analysis of the requirements for a successful business rescue order as set out in section 131(4) of the Companies Act 71 of 2008, University of Johannesburg, Johannesburg.

South African Institute of Chartered Accountants (SAICA), 2007, Trading whilst factually insolvent (revised 2007), South African Institute of Chartered Accountants, Johannesburg.

South African Institute of Chartered Accountants (SAICA), 2012, The SAICA guide to the Companies Act, South African Institute of Chartered Accountants, Johannesburg.

Stoop, H. \& Hutchison, A., 2017, 'Post-commencement finance - Domiciled resident or uneasy foreign transplant?', Potchefstroom Electronic Law Journa (Potchefstroomse Elektroniese Regsblad) 20(1), 1-41. https://doi.org/10.17159/ 1727-3781/2017/v20n0a1370.

Turnaround Management Association (TMA), 2011, Body of knowledge - Accounting and finance, Turnaround Management Association, Chicago, IL.

Van der Steen, P. \& Lake, D., 2019, Group five limited (in business rescue), business rescue plan, viewed 20 February 2020, from https://www.g5.co.za/pdfs/businessrescuse/group-five-limited-amended-business-rescue-plan.pdf.

Venuti, E.K., 2004, 'The going-concern assumption revisited: Assessing a company's future viability', CPA Journal 74(5), 40-43, viewed 15 May 2019, from https:// search.ebscohost.com/login.aspx?direct=true \&db=buh\&AN=13276883\&site=eh ost-live.

Yin, R.K., 2018, Case study research and applications: Design and methods, Sage, Los Angeles, CA. 